\title{
Environmental Linkages in Indonesian Language Learning
}

\author{
Assyifa Elfath / 18016141 \\ elfathassyifa@gmail.com
}

The environment is one component that influences the implementation of teaching and learning activities. The environment can also support teaching and learning activities in schools. The environment can also be a support in learning to write. In line with Amelia, Sukma, and Asma (2015) who state that learning to write experimental reports is able to: motivate students to learn to write in real terms because they collect data from objects or experimental phenomena for which the report will be written; Students feel challenged to explore their curiosity about natural phenomena that occur in the environment and generate interest in writing.

Teachers need to involve the environment in learning Indonesian. Because the environment can support learning activities, especially in learning to write. In line with Sari, Ramadhan and Rasyid (2018) teachers are a very decisive component in implementing a strategy in making the learning process effective. Teachers must be skilled at writing and skilled in using a suitable model in writing learning activities, because it can make it easier for students to develop thoughts when writing (Fitri, Syahrul, and Afnita, 2018).

Environmental learning is learning about the environment with internalization context directly or indirectly in forming independent personalities as well as patterns of actions and patterns of thinking of students so that they can reflect it into everyday life. Environmental learning is an effort to preserve and protect the environment and living ecosystems of living things that can contribute to the continuity of life that is balanced and more harmonious.

Environmental education material is an alternative choice to be applied to students so that they can develop patterns of thought and act, behave physically and mentally healthy in everyday life (Daryanto and SupRYin, 2013: 1) The relationship between environmental materials and Indonesian language learning is also stated in the Minang proverb which reads "nature takambang becomes a teacher" this shows that discourse materials (texts) with an environmental theme are one of the strategies to 
integrate environmental education which aims to shape and develop patterns of thought and action patterns, as well as healthy behavior both physically and mentally in everyday life as a result of educational activities.

The use of environmental materials in Indonesian language learning is able to trigger students 'interest in learning the language and by implication it can increase students' knowledge of the environment and the environment. In addition, this environment-based learning has the goal of making students participate in protecting and preserving the environment. The environment is also very influential for the smooth learning process in schools. This can be seen from the learning that goes directly to the field, such as making a paper about the environment that goes directly to environmental objects, and also becomes a variation of learning other than in the classroom. Therefore, students are important to increase and develop knowledge about the environment.

Environmental materials can help students to rethink the relationship between humans and the environment, understand and be aware of problems that occur in the environment and consider environmental problems related to life. Material about the environment is also used as material in Indonesian language learning such as news texts covering natural phenomena, descriptive texts about nature and its life, rhymes, poetry, and poetry lines that require natural and environmental materials and inspire literary / literary figures. leading. This is in line with Amin, Ramadhan, and Ermanto (2013) who state that the origin of regional names, customary law, and various kinds of wisdom are poured out through various myths, tales, tombos, and histories. The origin can be used as learning for students,

According to Buldur and Omeroglu (in Ramadhan et al, 2019), environmental education is important to increase students' attitudes and awareness of the environment. Environmental education should be designed to contribute to the cognitive, emotional, linguistic and psychomotor development of students, and enable students to develop positive attitudes towards the environment. In line with Suardi, Permatasari, Ramadhan and Asri (2019) who say that language acquisition in children in the phonological aspect is influenced by environmental factors, especially the family environment. This is indicated by the large number of vocabulary they get in the family environment and around them. 
The natural environment with its various biographies can be used as a source of inspiration in writing interesting reading materials and language learning. A number of endemic and unique fauna or flora, as well as unique cultural components, are used as learning and reading materials. So, not only integrated and contextual learning for Indonesian or English learning, but learning a number of subjects in the curriculum can be integrated and packaged in a multilingual manner (Mbete, 2015).

Environmental education can be integrated into other subjects, one of which is learning Indonesian. Integration can be done by using the theme of the environment in text learning. Through the text being studied, students can learn the language and gain environmental knowledge through the content of the text that is read (Ramadhan et al, 2019). In line with Sukma, Mahjuddin, Amelia (2017) who say that forcing a child to read immediately in a short time can affect their reading interest. Therefore, teachers need to create a pleasant environment for students so that students do not feel forced to learn Indonesian.

Being strong in the natural environment as a 'living space' for language learning is very important for students. Environmental issues that are manifested in the form of reading materials, illustrated pictures or photos, song texts, even posters about the beauty of nature are unique conservative ideas that can enrich students' insights to interpret and understand how important nature is to human life, either directly or indirectly (Tulalessy, 2016).

In environment-based learning, the environment can increase students' vocabulary. This is in line with Indriyani, Zaim, Atmazaki, and Ramadhan (2019) which state that literacy activities in language learning and focus on language skills processes can directly make students gain any knowledge. For example, environmental knowledge from texts with environmental themes; cultural knowledge from texts with cultural themes, and various other text themes.

Environment-based learning has the goal that students participate in protecting and preserving the environment. The environment is very important for the smooth learning process. Therefore, to develop knowledge about the environment is very important, because it can help students rethink human and environmental relations, 
understand the environment, be aware of environmental problems and consider environmental problems related to life (Ramadhan, Sukma, and Indriyani, 2019).

According to Tulalessy (2016) in language learning with the theme of the environment is an indication of being able to form intelligence of the heart, mind, and hands where the three competencies are related to one another. Language learning and teaching should be environmentally based. The natural environment around us is everything, so that the footsteps, the basic values of life, and the natural, natural, harmonious and harmonious orientation of life can be regenerated from an early age.

Based on a questionnaire that was distributed to 51 respondents consisting of 78.4\% women and 21.6\% men, who came from Padang State University, Bogor Agricultural Institute, Padang State Polytechnic, STIKIP Adzkia, UIN Bandung, Andalas University, University Fort De Kock, Jakarta State University, West Sumatra PGRI STKIP, Diponegoro University, West Sumatra Shipping Polytechnic, Ahmad Dahlan University, Padang Health Ministry of Health Poltekkes RI, and Gadjah Mada University. Obtained the following data. Point 1 states that students can observe the environment and make it a source of inspiration to make a literary work $56.9 \%$ strongly agree, $41.2 \%$ agree, $1.9 \%$ disagree, and $0 \%$ disagree. Point 2 states that the environment can be used as a theme in learning Indonesian 54, 9\% strongly agree, $43.1 \%$ of respondents agree, $2 \%$ disagree, and $0 \%$ disagree. Point 3 states that the environment is a source of inspiration in building linguistic intelligence. $54.9 \%$ agreed, 39.2\% strongly agreed, 5\% disagreed, and $0.9 \%$ disagreed. Point 4 states that in learning Indonesian, environmental-themed materials are a strategy to increase vocabulary. $51 \%$ agree, $47.1 \%$ strongly agree, $2 \%$ disagree and $0 \%$ disagree. Point 5 that environmental education in Indonesian language learning is important to improve students' attitudes and awareness of the environment, around $51 \%$ strongly agree, $47.1 \%$ agree, $1.9 \%$ disagree, and $0 \%$ disagree. Point 6 that learning about the environment can change the character of students in a more positive direction $51 \%$ agree, $45.1 \%$ strongly agree, 4.9\% disagree, and $0 \%$ disagree. Point 7 that environmental material can improve speaking skills by providing responses and arguments to the actual problem $51 \%$ agree, 43.1\% strongly agree, $5.9 \%$ disagree, and $0 \%$ disagree. Point 8 states that the environment can be used as material for discussion in learning Indonesian. $49 \%$ agreed, 
47.1\% strongly agreed, 3.9\% disagreed, and 0\% disagreed. Point 9 that solving environmental problems can be through learning Indonesian 49\% agree, 29.4\% strongly agree, $17.6 \%$ disagree, and $4 \%$ disagree. Point 10 that the use of the environment is one of the good media for Indonesian language learning to be applied in the learning process, because it fosters student interest and enthusiasm $47.1 \%$ agree, $45.1 \%$ strongly agree, 7.8 disagree, and $0 \%$ disagree. disagree.

Based on the results of studies and research by the author above, it can be concluded that the environment has an important role in learning Indonesian. Environmental materials can help students' skills and can foster interest and enthusiasm in learning Indonesian. Environmental material can also make it easier for students to understand Indonesian material well, increase students 'insight, and can build students' linguistic intelligence. Then environmental learning can be integrated into Indonesian subjects to provide comprehensive knowledge and skills in protecting the environment. This paper is used as material for joint evaluation for writers, readers and the general public to protect the environment together for environmental preservation. 


\section{REFERENCES}

Amelia, Rizky, Elfia Sukma, dan Nur Asma. (2015). Pembelajaran Menulis Laporan Percobaan Dengan Pendekatan Saintifik di Sekolah Dasar. Prosiding Seminar Nasional Jurusan PGSD FIP UNP. Vol.1, No.1

Amin, Irzal, Syahrul R, dan Ermanto. (2013). CERITA RAKYAT PENAMAAN DESA

DI KERINCI: Kategori dan Fungsi Sosial Teks. Jurnal Bahasa, Sastra dan Pembelajaran. Vol. 1, No. 1

Fitri, Margian Mulya, Syahrul R., Afnita. (2018). Pengaruh Model Discovery Learning

Berbantuan Media Gambar Berseri Terhadap Keterampilan Menulis Teks Eksplanasi Siswa Kelas VIII SMP Negeri 25 Padang. Jurnal Pendidikan Bahasa dan Sastra Indonesia. Vol. 1, No. 7

Indriyani, Vivi, M. Zaim, Atmazaki, dan Syahrul Ramadhan. (2019). Literasi Baca

Tulis Dan Inovasi Kurikulum Bahasa. KEMBARA: Jurnal Keilmuan Bahasa, Sastra, dan Pengajarannya. Vol. 5, No. 1

Mbete, A. M. (2015). Pembelajaran Bahasa Berbasis Lingkungan: Perspektif Ekolinguistik. RETORIKA: Jurnal Ilmu Bahasa, 1(2), 352-364.

Sari,Yuliana, Syahrul R, dan Yulianti Rasyid. (2018). Hubungan Antara Keterampilan Membaca Pemahaman Dengan Keterampilan Menulis Teks Laporan Hasil Observasi Siswa Kelas X SMK Negeri 3 Padang. Jurnal Pendidikan Bahasa dan Sastra Indonesia. Vol. 7, No.3

Suardi, Indah Permatasari, Syahrul R, dan Yasnur Asri. (2019). Pemerolehan Bahasa Pertama pada Anak Usia Dini. Jurnal Obsesi : Jurnal Pendidikan Anak Usia Dini. Vol. 3, No. 1

Sukma, Elfia, Ritawati Mahjuddin, dan Rizky Amelia. (2017). Literacy Media

Development in Improving Reading and Writing Skill of Early Class Students in Elementary School Padang Utara Padang. Advances in Social Science, Education and Humanities Research. Vol. 118

Ramadhan, S., Sukma, E., \& Indriyani, V. (2019). Environmental Education And Disaster Mitigation Through Language Learning. In IOP Conference Series: Earth and Environmental Science (Vol. 314, No. 1, p. 012054). IOP Publishing. Tulalessy, Q. D. (2016). Pembelajaran Bahasa Berbasis Lingkungan sebagai Upaya Membangun Kecerdasan Ekologis. Jurnal Triton Pendidikan, 1(1), 51-56. 


\section{ATTACHMENT}

Table 1

Questionnaire on the Relationship of Indonesian Language Learning with the Environment

\begin{tabular}{|c|c|c|c|c|c|}
\hline NO & Question & SS & $\mathbf{S}$ & $\mathbf{K S}$ & TS \\
\hline 1 & $\begin{array}{l}\text { Students can observe the environment } \\
\text { and make it a source of inspiration to } \\
\text { create a literary work. }\end{array}$ & $56.9 \%$ & $41.2 \%$ & $1.9 \%$ & - \\
\hline 2 & $\begin{array}{l}\text { The environment can be used as a theme } \\
\text { in learning Indonesian. }\end{array}$ & $54.9 \%$ & $43.1 \%$ & $2 \%$ & - \\
\hline 3 & $\begin{array}{l}\text { The environment is a source of } \\
\text { inspiration in building linguistic } \\
\text { intelligence. }\end{array}$ & $39.2 \%$ & $54.9 \%$ & $5 \%$ & $0.9 \%$ \\
\hline 4 & $\begin{array}{l}\text { In Indonesian language learning, } \\
\text { environmental-themed materials are a } \\
\text { strategy to increase vocabulary. }\end{array}$ & $47.1 \%$ & $51 \%$ & $2 \%$ & - \\
\hline 5 & $\begin{array}{l}\text { Environmental education in Indonesian } \\
\text { language learning is important to increase } \\
\text { students' attitudes and awareness of the } \\
\text { surrounding environment. }\end{array}$ & $51 \%$ & $47.1 \%$ & $1.9 \%$ & - \\
\hline 6 & $\begin{array}{l}\text { Learning about the environment can } \\
\text { change the character of students in a more } \\
\text { positive direction. }\end{array}$ & $45.1 \%$ & $51 \%$ & $4.9 \%$ & - \\
\hline 7 & $\begin{array}{l}\text { Environmental materials can improve } \\
\text { speaking skills by providing responses } \\
\text { and arguments to actual problems. }\end{array}$ & $43.1 \%$ & $51 \%$ & $5.9 \%$ & - \\
\hline 8 & $\begin{array}{l}\text { The environment can be used as material } \\
\text { for discussion in learning Indonesian. }\end{array}$ & $47.1 \%$ & $49 \%$ & $3.9 \%$ & - \\
\hline 9 & $\begin{array}{l}\text { Environmental problem solving can be } \\
\text { through learning Indonesian. }\end{array}$ & $29.4 \%$ & $49 \%$ & $17.6 \%$ & $4 \%$ \\
\hline 10 & $\begin{array}{l}\text { Utilization of the environment is one of } \\
\text { the Indonesian language learning media }\end{array}$ & $45.1 \%$ & $\begin{array}{c}47.1 \\
\&\end{array}$ & $7.8 \%$ & - \\
\hline
\end{tabular}




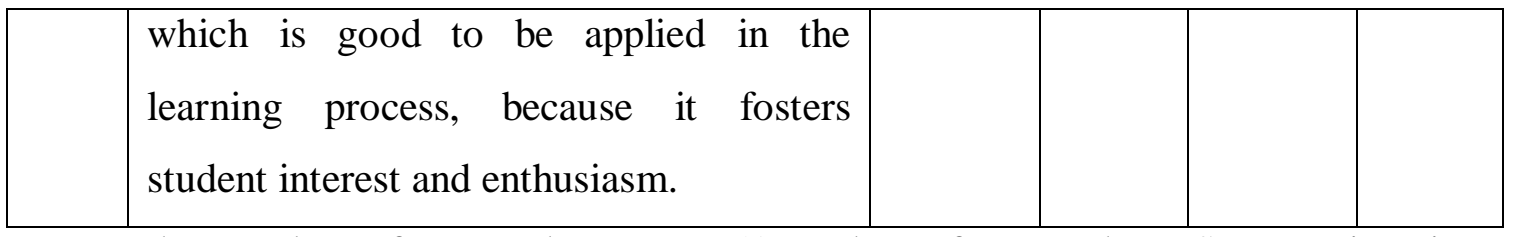

The number of respondents was 51 students from Padang State University, Bogor Agricultural Institute, Padang State Polytechnic, STIKIP Adzkia, UIN Bandung, Andalas University, Fort De Kock University, Jakarta State University, STKIP PGRI West Sumatra, Diponegoro University, West Sumatra Shipping Polytechnic, Ahmad Dahlan University, Poltekkes Kemenkes RI Padang, and Gadjah Mada University.

\section{Information:}

SS : Strongly agree

$\mathrm{S} \quad$ : Agreed

KS : Disagree less

TS : Disagree 